\title{
A Experiência do Monólogo, Autoria e Construção de Si
}

\author{
Ana Amélia Brasileiro Medeiros Silva*
}

Resumo: Este trabalho apresenta algumas reflexões preliminares sobre minha tese de doutorado em que analiso a experiência de atores e atrizes na criação de monólogos, no Rio de Janeiro, entre 2007 e 2008. Este trabalho enfoca a questão da autoria que envolve tais projetos cênicos solo, relacionada com perspectivas sobre a autonomia artística, a autenticidade e a unicidade, nas complexas imbricações entre o artista (ator/indivíduo) e sua obra (monólogo/performance/encenação/texto). Tais questões se relacionam mais amplamente com as noções de pessoa e indivíduo e aqui estão associadas à exploração, por parte dos atores $e$ atrizes autores, de uma experiência artística pessoal, em que visões sobre um "teatro seu" ("próprio" de um ator ou atriz, em que a própria diferenciação tradicional entre ator e seu personagem é desafiada) são postos em primeiro plano. Para esta abordagem ainda preliminar, tomo como recorte dois monólogos e a experiência de criação de suas autoras, de um total de oito espetáculos solos a serem analisados na tese. Eles são Anticlássico: uma desconferência ou o enigma vazio, concebido e encenado pela atriz Alessandra Colasanti e A Alma Imoral, de Clarice Niskier.

Palavras-Chave: Performance teatral, monólogo, autoria, subjetividades artísticas.

\begin{abstract}
This paper presents some preliminary analyses on my doctorate thesis where I investigate the experience of actors and actresses in the creation of monologues, in Rio de Janeiro, between 2007 and 2008. This work focuses on the matter of authorship that involves such scenic projects, related with perspectives on the artistic autonomy, the authenticity and the unicity, in the complex interplay between the artist (actor/individual) and her/his craft (solo performances/staging/text). Such questions are related more widely with the notion of person and individual and, here, are associated with this actors and actresses' personal artistic experience and authorship, where perspectives on a "personal theater" (linked to a personal kind of performance, which challenges the boundaries between actor and the fictional character) are emphasized. At this point, this paper analyses two monologues, out of eight spectacles analyzed in the thesis, and the authorial experience involving their respective leading actresses. They are "Anticlássico: uma desconferência ou o enigma vazio", created and staged by Alessandra Colasant, i and "A Alma Imoral", by Clarice Niskier.
\end{abstract}

Keywords: Theatre Performance, monologue, authorship, artistic subjectivities.

\footnotetext{
* Doutoranda do PPCIS/UERJ, ligada à linha de pesquisa Imagens e Perspectivas da Subjetividade, e mestre em Sociologia e Antropologia pelo PPGSA/UFRJ. Este texto é uma versão do artigo apresentado no XIV Congresso Brasileiro de Sociologia, ocorrido entre os dias 28 a 31 de julho de 2009, no Rio de Janeiro, dentro do GT de Sociologia da Arte.
} 


\section{1-Introdução}

Este trabalho apresenta algumas reflexões preliminares sobre minha tese de doutorado em que analiso a experiência de atores e atrizes na criação de monólogos, cujas carreiras tenham se desenrolado no Rio de Janeiro de um ano para cá e/ou ainda se encontram em processo. Este trabalho tem como foco particular a questão da autoria em torno de tais projetos cênicos solo, a qual se relaciona com perspectivas sobre a autonomia artística, a autenticidade e a unicidade, nas complexas imbricações entre produtor (ator/indivíduo) e sua obra (monólogo/performance/encenação/texto). Tais questões se relacionam mais amplamente com as noções de pessoa e indivíduo que sustentam e ao mesmo tempo são sustentadas por elas. Através desta pesquisa, busca-se uma perspectiva mais aprofundada em torno da exploração, por parte dos atores e atrizes autores, de uma experiência artística pessoal, em que visões sobre um "teatro seu" (reconhecido como "próprio" de um ator ou atriz, em que a própria diferenciação tradicional entre ator e seu personagem é desafiada) são postos em primeiro plano, e por consequiência dinamizam e realimentam perspectivas em torno da construção de si, próprias de uma noção ocidental de indivíduo que se expressa por um sujeito capaz de se autodefinir, mas que neste contexto pode ser relativizada.

Para esta abordagem ainda preliminar, tomo como recorte dois monólogos e a experiência de criação de suas autoras, de um total de oito espetáculos solos a serem analisados na tese. Eles são Anticlássico: uma desconferência ou o enigma vazio, concebido e encenado pela atriz Alessandra Colasanti e A Alma Imoral, de Clarice Niskier. Tais espetáculos, assim como o ponto de vista de suas encenadoras, serão tratados mais detalhadamente à frente. Antes disso, acredito ser interessante situar algumas definições sobre o monólogo, sobretudo dentro do campo da crítica teatral, para nos aproximarmos de seus traços mais específicos e como estes podem se relacionar com esta experiência de autodeterminação dos sujeitos criativos envolvidos.

\section{2 - O que é que o monólogo tem? A perene desconfiança em torno de gênero.}

Um primeiro desafio é localizar uma definição do que é o monólogo teatral e a sua relação específica com o trabalho do ator - ou com o processo de se tornar um tipo 
específico de artista através da construção de um projeto solo. O monólogo, literalmente o discurso de uma só pessoa, é descrito por Pavis (1999), numa contraposição à cena dialógica, como "um discurso que a personagem faz a si mesma" e, segundo esta visão preliminar do teórico do teatro, caracteristicamente marcado pela "ausência de intercâmbio verbal". O contexto teórico a partir do qual esta definição inicial se estrutura é o do teatro de convenções realistas, onde basicamente, a história encenada no palco se desenrola "como se fosse de verdade", e não assumidamente como uma construção artística para o palco. Aqui, buscar-se-ia um tipo de ilusão que imprime no palco uma realidade mimética, onde toda a ação acontece atrás de uma "quarta parede" invisível que separa o palco da platéia, apoiada na idéia de verossimilhança. Desta maneira, o monólogo, a ação de alguém falar sozinho ${ }^{1}$, em situações realistas só poderia surgir em momentos excepcionais, justificados pelo sonho, pela embriaguez, pelo sonambulismo ou efusão lírica.

Pela convenção realista e naturalista, o monólogo se inscreve nos limites da verossimilhança pela simples noção do bom senso $^{2}$ de que seria absurdo, numa situação "real”, uma pessoa (a não ser um louco ou variações em torno do tema) revelar em voz alta, a si mesma, seus sentimentos, pensamentos, raciocínios. Entretanto, como sublinha Pavis (idem), no contexto contemporâneo, pós-brechtiano, o que está no foco é o conjunto dos discursos da peça e não a consciência isolada dos personagens individualizados. Em um panorama composto de múltiplas possibilidades, desconstruções e redefinições acerca da linguagem teatral, o monólogo ganharia força como forma discursiva exatamente por seu caráter desafiador do jogo realista - através dele é possível explorar novas dramaturgias e práticas teatrais. Ele se combina produtivamente a experimentos que questionam o próprio status da linguagem como representação da realidade ou, ainda, a própria possibilidade de representação de uma realidade; o monólogo alia-se a dramaturgias que enfatizam a experiência subjetiva do fluxo da consciência em detrimento do suposto artificialismo do diálogo entre

\footnotetext{
${ }^{1}$ Não obstante, falar sozinho para si mesmo pode ser interpretado como um modo de diálogo, como é apontado por Benveniste (1974 apud PAVIS, 2007, pp.85-86), ainda nos limites da verossimilhança realista, quando é encarado como um diálogo interior entre um "eu" locutor e um "eu" ouvinte.

${ }^{2}$ É interessante notar que, em algumas entrevistas com atores que nos últimos anos encenaram monólogos no Rio de Janeiro, a situação de "falar sozinho", vista como absurda pelo bom senso (pelo menos na perspectiva dos teóricos do teatro e da dramaturgia), é defendida como relativamente usual na "vida real". Ou seja, busca-se uma justificação para o monólogo não apenas como um gênero discursivo teatral, mas como uma situação factível, realista.
} 
personagens com idéias coerentes e compartilháveis (visto como uma irrealidade por muitos autores). Tais dramaturgias apostam na relação dialógica entre o ator e o espectador - este, no caso, reflexivamente engajado, que interpreta e dá sentidos particulares à voz que se expressa em cena ${ }^{3}$.

Assim, o monólogo, antes de ser o discurso de uma pessoa, tem a potência de se constituir, por exemplo, como uma mise en scène em que vários discursos se desenrolam, através de muitas personagens, vividas por apenas um ator ou atriz, que assim o faz sem que os espectadores deixem de se envolver reflexiva, imaginativa e emocionalmente com a narrativa, entrando no jogo cênico a partir de novos pactos entre a realidade da platéia e a realidade da cena.

Dessa forma, o monólogo, aparentemente de modo mais radical que em situações onde há mais de um ator em cena (nas quais os atores se concentrariam no diálogo entre si), acaba por redimensionar a relação, em geral subjacente, com o público - para quem, afinal, qualquer diálogo ou ação são direcionados. O monólogo afirma a presença do público e sua condição de destinatário direto, explícito, da mensagem proferida pelo ator solo em cena. Mesmo quando o monologante fala para si, para o seu eu ouvinte e não rompe ostensivamente a quarta parede, sua fala e ação dirigem-se diretamente para o espectador, que é interpelado como cúmplice e voyeur ouvinte.

Há situações, por exemplo, em que o ator quebra abertamente a quarta parede, incluindo o próprio público na cena, sustentando assim, ironicamente, a verossimilhança. Este é o caso das duas peças/experiências de criação que trato neste trabalho. Em ambas, a platéia é explicitamente envolvida na cena. Em Anticlássico, o público é assumidamente a platéia fictíca de uma palestra proferida pela protagonista da peça, a Bailarina de Vermelho, e, em A Alma Imoral, o público tem a sua presença afirmada na peça, bem como a sua relação com a própria performance de Clarice Niskier, ao ser convidado a falar com a atriz em cena (e não a personagem, que, segunda a atriz, não há), numa relação direta e frontal onde a cena se faz sem ligação com os tradicionais recursos da ilusão realista, misturando várias possibilidades expressivas e gêneros discursivos.

\footnotetext{
3 Com relação ao teatro "pós-moderno", do qual podemos aproximar as experiência monológicas contemporâneas, Pavis (2007: p.299) chama a atenção para a supervalorizçao do pólo da recepção e da percepção: o espectador deve organizar impressões divergentes e convergentes e restituir certa coerência à obra, graças à lógica das sensações e a sua experiência estética. A obra pós-moderna, na sua versão mais radical (próxima à arte da performance, como veremos), não tem outra referência que não ela mesma, deixando o espectador diante de uma "representação emancipada".
} 
Novamente do ponto de vista dos críticos e teóricos do teatro, esta poderosa relação direta com o público constitui ao mesmo tempo a força e a precariedade do gênero, ligada ao risco da inverossimilhança. Num contexto de encenação calcada no realismo, o monólogo facilmente revelaria a artificialidade da representação teatral, caindo no ridículo, no constrangedor e irreal. Mais ainda, o monólogo é visto com desconfiança por causa de seu sentido anti-dramático, estático e mesmo tedioso.

É digno de nota o verbete dedicado ao monólogo do "Dicionário do Teatro Brasileiro: temas, formas e conceitos", lançado em 2006. Após nos advertir sobre a dificuldade intrínseca de sustentar o interesse do público em um só intérprete em cena ${ }^{4}$, o fenômeno do aumento significativo de produções solo na cena contemporânea brasileira $^{5}$, com relativo sucesso de público e crítica, é comentado (ou justificado) muito brevemente, levando-se em conta só e basicamente dois pontos: o seu relativo baixo orçamento e um certo aproveitamento da consagração na tevê, por seus protagonistas, para garantir o interesse do público em seus espetáculos-solo ${ }^{6}$. De fato, diante do considerável surgimento de monólogos, que de temporada em temporada se renovam pelos palcos cariocas, chamando atenção não só da crítica especializada, mas, sobretudo, do público (fato que poderia ser encarado como ainda mais intrigante), o verbete parece ser por demais lacônico quanto à representatividade do gênero no teatro contemporâneo brasileiro ${ }^{7}$.

\footnotetext{
${ }^{4}$ Daí a exigüidade de textos e apresentações monológicas no passado do teatro brasileiro, ligada também à própria organização da produção teatral até as décadas de 60 e 70, baseada em companhias teatrais compostas por grandes elencos mantidos sob contrato.

${ }^{5}$ Em um levantamento preliminar, constatei que havia, de fato, uma considerável presença de monólogos em cartaz no Rio de Janeiro entre setembro de 2006 e abril de 2008, já recorrentemente sublinhada pela crítica e jornalistas. Com uma média mensal de 54 espetáculos em cartaz (nos 17 meses pesquisados, mais o mês de abril de 2008, acessado pelo site da OFF, num total de 18 meses), destes, 11 eram monólogos, ou seja, próximo a $20 \%$ das produções. Ainda foi possível notar a longevidade de diversos monólogos, bem como a renovação dos mesmos. Outro dado interessante foi o da diversidade. Muitas comédias se destacaram, mas também textos com propostas mais heterodoxas, como o grande sucesso "A Alma Imoral", protagonizado pela atriz Clarice Niskier, ou "Soppa de Letra", concebido e estrelado pelo ator Pedro Paulo Rangel, que estreou em 2004 e teve uma breve nova temporada em 2007. Inclusive, ambos receberam o Prêmio Shell de melhores atriz e ator: Clarice Niskier em 2006 e Pedro Paulo Rangel em 2004, pelos respectivos monólogos.

${ }^{6}$ Segundo Guinsburg, "motivados em parte pela economia da produção e interpretados (e muitas vezes escritos) por atores que fazem sucesso na televisão, como Miguel Falabella, Pedro Cardoso e Diogo Vilela" (2006, p.187).

${ }^{7}$ Meu foco é a produção carioca, que, sem dúvida, é ultrapassada em muito, numericamente, pela de São Paulo. No entanto, é, certamente, o locus de muitas das produções que passam a compor o que o campo da história e crítica do teatro brasileiro toma como de mais representativo no panorama contemporâneo de produção cênica. E da mesma forma, as produções também consideradas mais representativas de outras regiões - sobretudo de São Paulo, Curitiba e Belo Horizonte - passam pelo Rio de Janeiro na trajetória de suas carreiras.
} 
O que temos é um discurso ambivalente sobre os monólogos atuais, que surge em outros contextos dentro do campo artístico. Trazendo a discussão para o campo teatral do Rio de Janeiro, se, por um lado, chama atenção a profusão de monólogos em cartaz na cidade, relativamente a todas as dificuldades em torno do gênero já expostas, por outro, a mesma crítica que olha com desconfiança o fenômeno, ano a ano premia calorosamente os solistas e as suas propostas cênicas, assim como o mesmo público que rejeitaria os monólogos lota os teatros da cidade para ver apenas um ator ou atriz em cena.

Como aponta a mais famosa crítica de teatro carioca, Bárbara Heliodora, em declaração publicada na Revista Aplauso, especializada na divulgação das peças em cartaz no Rio de Janeiro, na edição de novembro de 2007, a "chuva de monólogos que nos atinge" seria uma conseqüência (aparentemente negativa) da falta de recursos e investimentos na produção teatral brasileira. Para ela, não seria "por livre escolha que hoje em dia as pessoas fazem monólogos, peças de duas pessoas, superproduções de três...". A pulverização de verbas para o teatro, a partir de critérios, segundo ela, mais assistencialistas que artísticos, impossibilitaria o investimento em produções de "temas relevantes", nas quais fosse possível unir e remunerar bem grandes elencos, assistidos por bons profissionais técnicos e artísticos. A partir das observações da crítica, é importante se destacar dois pontos: o primeiro é o de que o monólogo parece ser um gênero menor, pois não seria a primeira escolha de ninguém, em oposição aos grandes espetáculos, mais representativos do que seria um rico ambiente teatral; o segundo ponto diz respeito à relação, quase imediata, entre monólogo e baixo orçamento (também apontada no "Dicionário de Teatro Brasileiro"), sendo a escassez de recursos o principal fator causal da "chuva de monólogos que nos atinge".

Outro ponto que coloca o monólogo numa posição de ambivalência dentro do discurso crítico liga-se a sua associação com a comédia. Lionel Fisher, importante crítico de teatro carioca, associa o fenômeno dos monólogos no Rio de Janeiro - que já intrigava os teóricos há dez anos - à fácil aprovação da comédia. Para ele, a profusão de monólogos em cartaz na época, na sua maioria esmagadora cômicos, é explicada pela carência e necessidade infantil de aprovação do ator brasileiro, que "vende a alma por um riso"(BERNAT, 1999, p.24). A comédia parece ser vista predominantemente com restrições pela crítica "séria", comprometida com um teatro que privilegia os "temas 
relevantes", "faça pensar" ou que seja "sensível"8. Tal visão negativa em torno da comédia surge como um fator relativizador (e desmerecedor) da possível significância da produção de monólogos, já observada na década de 90.

Corroborando a lógica da popularidade da comédia descrita acima, em reportagem do "Segundo Caderno" do jornal "O Globo", de 22/04/2007, a qual apresenta uma pesquisa encomendada pelo Instituto Fecomercio ${ }^{9}$ sobre os hábitos, queixas e anseios dos espectadores de teatro da cidade, a comédia surge como a grande favorita do público que vai ao teatro. $\mathrm{E}$, aqui, a ambivalência com relação às peças-solo revela-se por sua grande aceitação de público, “apesar de ser monólogo". Nos pequenos depoimentos dos protagonistas de monólogos em cartaz na época da pesquisa, os elogios do público em relação a suas peças flagram este caráter ambíguo: "É monólogo, mas é bom" ou "Nem parece monólogo!" - tais são exemplos das "críticas positivas" ouvidas com frequiência. A partir da matéria, parece que o monólogo, como gênero, é visto pelo público como potencialmente monótono, com tendência a ser intelectualizado demais, logo, chato. No entanto, no processo decisório pela peça a ser vista, o fato de ser monólogo parece não afetar de modo significativo a escolha pelo programa. As peças de sucesso de público com apenas um ator em cena, antes de serem enquadradas na categoria "monólogo", parecem estar associadas ao fato de serem comédias ou musicais ou simplesmente reconhecidas como boas pela crítica e pelo boca-a-boca. Montar um monólogo, assim, parece ser um desafio duplo: por um lado, o de conquistar a crítica, que vê o monólogo a priori com restrições, ainda mais se for uma comédia, e, por outro, de agradar ao público, mesmo se for comédia, pois, como a pesquisa revela, ele ainda desconfia do potencial de comicidade em um monólogo (visto tradicionalmente como monótono). Não obstante, a constatação de que alguns dos melhores - e mais caros - teatros da cidade estiveram ocupados pelos monólogos na

\footnotetext{
${ }^{8} \mathrm{Na}$ minha dissertação de mestrado (SILVA, 2003) exploro, ainda que perifericamente, alguns critérios que estabelecem valores de distinção dentro do campo das artes cênicas. Percebeu-se, assim como aponta Bourdieu sobre a ideologia da Estética em "La distinction" (1979), a recusa do "fácil", do "simples", "sem profundidade", do "barato", a qual se traduziria, particularmente para o meu campo, em uma visão negativa com relação à maior parte dos trabalhos em televisão, ao "teatro comercial" e de "entretenimento". Aqui, a comédia entra como a grande expressão do apelo ao "comercial", "fácil", "popular", "superficial" e mesmo "vulgar", pois, como explicitamente aponta Fisher, no papel de voz dominante do campo, ela se relacionaria aos aspectos mais "infantis", pouco cultivados e sofisticados, tanto do ator quanto da platéia.

${ }^{9}$ Segundo a matéria, "a enquete, feita em março, revelou que 79,5\% da população do Grande Rio já foram ao teatro pelo menos uma vez este ano, sendo que $83,6 \%$ dessa parcela - quase a totalidade das pessoas que já assistiram a alguma peça em 2007 - vão ao teatro pelo menos uma vez por mês".
} 
ocasião da pesquisa (fenômeno que tem se repetido com considerável frequência) é bastante representativa da força das produções no sentido de atrair o público, apesar de aparentemente o sucesso ser sempre visto como exceção a uma regra em que o monólogo é um gênero menor ou pouco popular.

Ao longo da matéria encontramos o mesmo discurso que explica o número de monólogos em cartaz por questões exclusivamente mercantis, pela carência generalizada de recursos para as produções teatrais (que depende de políticas públicas) e a inexistência de uma indústria do espetáculo autossuficiente. Acredito que limitar as perspectivas sobre o fenômeno (quantitativo e qualitativo) dos monólogos a supostas estratégias de mercado (seriam escolhidos por serem em si baratos e logisticamente descomplicados; atrela-se seu sucesso de público ao fato de terem "globais" ou serem comédias) acaba obliterando um olhar em torno de questões, que me parecem, particularmente mais significativas sobre a experiência dos trabalhos solo, sobre o que eles dizem de seus criadores e de seus espectadores, e sobre as possibilidades discursivas do indivíduo contemporâneo em busca de um tipo de autodeterminação, não só artística, mas de modo bem mais amplo e complexo, socioidentitária (que ao mesmo tempo é, reflexivamente, vivada como processo que desafia qualquer categorização sedimentada).

Uma perspectiva que busca significados alternativos e mais amplos em torno do fenômeno do monólogo é revelada nos recentes trabalhos da pesquisadora do teatro Maria Helena Werneck. Seu projeto de pesquisa, voltado para a constituição de um corpus de textos e espetáculos que se inscrevem no gênero monólogo (peça com apenas um ator em cena) no Brasil, chama a atenção para a constituição e desenvolvimento desta forma específica de teatro, a qual tem reafirmado procedimentos discursivos próprios, misturando os gêneros épico, lírico e dramático, engendrando diferentes modos de atuar e "alçando o ator a um patamar de composição interpretativa que tanto pode funcionar como iniciação quanto pode dar margem ao reconhecimento consagrador"(2006, p.230).

Contemporaneamente, o monólogo, segundo o ponto de vista de Maria Helena Werneck, está em transformação, ocupando o campo, em gestação, da "criação cênicodramatúrgica de atores que reivindicam para si a autoria do texto e, muitas vezes, assinam a concepção de atuação e de proposta cênica, atualizando, principalmente, a função-ator" (idem). Sob este aspecto, a autora sublinha os trabalhos autointitulados 
solo ou autoperformáticos, nos quais "os componentes do enredo e de composição cênica podem estabelecer um pacto autobiográfico, que diz respeito à autenticidade dos eventos narrados, à história pessoal e aos percursos de formação e treinamento do ator" (idem). Nesta pesquisa sobre os monólogos, a autora ressalta a importância da entrada de novos autores (também atores) no panorama teatral, os quais optaram por esta forma teatral "na busca de liberdade de experimentação e de economia dos meios de produção"(idem). Estas observações da pesquisadora se alinham, de forma muito privilegiada, às minhas primeiras impressões sobre a particularidade do fenômeno dos trabalhos solos, que vai bem mais além da simples questão da economia e suposta facilidade de produção.

Dentro do campo de pesquisa em artes cênicas, a autora aponta como temas privilegiados de investigação acerca dos monólogos: "o estatuto ficcional da fala em primeira pessoa e as fronteiras dos gêneros discursivos da memória, da autobiografia, do testemunho e confissão etc.; as convenções cênicas do monólogo e as espacialidades (a ênfase na frontalidade, a produção da intimidade ou teichoscopia, a imersão no espaço tridimensional da instalação); as referências do trabalho do ator: a herança renovada do diseurs, a atuação histérica, o desenho coreográfico, a mimesis realista e a antimimesis" (idem). Estes pontos me parecem muito úteis como uma forma de guia para perceber a especificidade do gênero dentro do próprio campo de visão e criação nativa, suas linguagens e questionamentos particulares. Não obstante, o tipo de preocupação investigativa da autora, apesar de partir de questões que coincidem num primeiro momento com as minhas próprias - a experiência específica do monólogo, a questão da autoria, autonomia e exploração da autorreferência individual na construção da obra -, tem como objetivo tipos de reflexões de natureza distinta. A pesquisa de Werneck volta-se para a crítica e historiografia cênica, literária e artística. No meu caso, o foco é a interrogação sociológica e antropológica acerca de experiências ligadas a noções do individualismo contemporâneo, o que será especificado mais à frente.

\section{3 - Duas propostas de estar só em cena: "Anticlássico" e "A Alma Imoral”}


Para os propósitos desta exposição, comentarei brevemente duas experiências monológicas que venho pesquisando (num total de oito ${ }^{10}$ ), que acredito sejam representativas, ou boas para pensar, das questões sociológicas mais amplas que pretendo explorar. O primeiro monólogo a ser tratado é Anticlássico: uma desconferência ou o enigma vazio, escrito e protagonizado pela atriz Alessandra Colasanti, e o segundo é A Alma Imoral, escrito e protagonizado pela atriz Clarice Niskier. Ambas as atrizes, com histórias de formação e carreiras profissionais bem diversas, buscam a exploração, a investigação e configuração de uma forma pessoal de fazer teatro, de um teatro apropriado ao que elas pensam, sentem, acreditam como indivíduos.

Ambas dão vida, atualmente, a projetos assumidamente autorais e solos, em que as "personagens" que colocavam em cena, de modos muito próprios, fazem parte da história das atrizes - não no sentido biográfico mais óbvio ou direto (representar a si mesma em determinadas situações vividas), mas no sentido de encenarem questões que as envolvem intima e pessoalmente. Estas se referem não somente ao conteúdo do que é encenado (por exemplo, Clarice Niskier sobre a transgressão e Alessandra Colasanti sobre a crítica do campo artístico), mas também a um modo particular de fazer teatro, de estar em cena, de representar ou atuar (por exemplo, distanciando-se ou mesmo negando a representação realista ou o tipo de personagem psicologizado do drama burguês).

Apesar dos pontos de contato superficiais, os dois projetos se ligam a temáticas e discutem questões, formas de atuação e perspectivas sobre a própria expressividade do ator bastante diversas.

Alessandra Colasanti, 35 anos, é filha de conhecidos intelectuais brasileiros e formada há 5 anos pela Casa das Artes de Laranjeiras (apesar de fazer teatro desde a adolescência), no Rio de Janeiro. Ela, no curto período em que tem participado de montagens teatrais cariocas, vem recebendo excelentes críticas sobre seu trabalho como atriz e diretora e indicações a importantes prêmios de teatro. O projeto Anticlássico: uma desconferência ou o enigma do vazio, também muito elogiado, define-se, segundo o programa de sua apresentação na Casa do Saber em maio de 2007, como:

\footnotetext{
${ }^{10}$ As outras seis peças são: "Minha mãe é uma peça", com Paulo Gustavo; "O Animal do Tempo", com Ana Kfouri; "Os Homens são de Marte... e é pra lá que eu vou", com Monica Martelli; "A Mulher que Escreveu a Bíblia", com Inês Viana; "Simplesmente Eu", de Beth Goulart e "Comício Gargalhada", de Rodrigo Sant`Anna.
} 
"uma provocação satírica não apenas ao cânone, mas à linguagem acadêmica e aos castelos de nuvem conceitual erigidos sobre o nada. A peça propõe uma reflexão sobre cultura e linguagem, pensa através de seus procedimentos textuais e cênicos o gênero monólogo, a retórica acadêmica, o discurso, a arte e a sociedade contemporâneas. É através do humor irônico, a um só tempo sofisticado e pop, que a atriz, diretora e autora Alessandra Colasanti destila sua crítica. Em cena, a "bailarina" conduz a narrativa em formato de palestra com direito a projeções, vídeos ilustrativos, perguntas da audiência e coffee break."

$\mathrm{O}$ projeto performático de Alessandra ligado à sua crítica muito particular à linguagem e retórica acadêmicas, às labirínticas discussões e disputas em torno do significado da arte, dos valores da modernidade e da pós-modernidade, não se circunscreve à apresentação do Anticlássico. Ele se corporifica na figura da Bailarina de Vermelho, sua alter ego performática, cujas observações e comentários sobre o mundo contemporâneo continuam a ganhar forma - e a se apresentar - no seu blog na internet (http://abailarinadevermelho.blogspot.com), que tem a seguinte chamada: "(Cansada do Velho Mundo) A Bailarina de Vermelho está no Brasil em busca de pistas que possam ajudá-la a solucionar o glorioso, e famoso, e portanto paradoxal, Enigma Vazio”.

Os posts que compõem o blog, de autoria da própria Bailarina de Vermelho, enredam cenários, situações e personagens reais em narrativas absurdas, cheias de humor e fina ironia (muitas vezes auto-ironia) - reportam suas impressões de uma visita ao MAM, o Museu de Arte Moderna do Rio de Janeiro, e ao "Museu Internacional de ArteFruti Pão de Açúcar", que estaria em São Paulo, seguida de uma bem ilustrada entrevista com o próprio Pão de Açúcar; comentam seus encontros com personalidades da cultura brasileira, reais, supostos e prováveis, tais como o deputado Ciro Gomes, em plena folia carnavalesca, ou o casal Jorge Amado e Zélia Gatai - refletidos na imagem dos pais de Alessandra, Afonso Romano de Sant'Anna e Marina Colasanti. E ainda, encontramos no blog uma entrevista com Che Guevara, a transcrição de um desabafo de Duchamp, notícias de perseguições ideológicas sofridas pela Bailarina, acusada de "colocar cabelo em ovo".

Mais do que criar uma espécie de jornal próprio ao universo da Bailarina, em continuidade com a "desconferência" apresentada sob a peça Anticlássico, o blog nos

\footnotetext{
${ }^{11}$ Críticas, cartazes e releases sobre a peça em anexo. Para ver alguns vídeos sobre o "Anticlássico" pela internet: http://www.youtube.com/watch?v=rMDINt1grt4; http://www.youtube.com/watch?v= ZALSZa-FQ; http://www.youtube.com/watch?v=WYwAjc3G7IQ\&feature=related.
} 
informa, com seus links para vídeos e seqüências de fotos on-line, que a Bailarina continua efetivamente em ação. Suas várias apresentações performáticas, nos mais diferentes ambientes, se encontram ali parcialmente registradas. Não obstante, os vídeos e fotos das performances não são apenas "registros", mas artefatos artísticos em si mesmos, que ela mesma produz. Nas fotos, textos e vídeos, que são partes integrantes da performance, de modo mais radical e imprevisível, a figura da atriz (e também "amiga", "filha", "colega", "personalidade”, dependendo da relação que tem com seus interlocutores) se funde à própria figura da Bailarina de Vermelho. ${ }^{12}$

O outro projeto cênico para o qual volto meu olhar, A Alma Imoral, estreou timidamente no Rio e tornou-se um grande sucesso. Ficou 14 meses em cartaz na cidade, tendo sido visto por mais de 60 mil pessoas, seguiu tournée nacional por quatro meses e atualmente está em cartaz, com grande sucesso, na cidade de São Paulo ${ }^{13}$.

Após ler e se impressionar profundamente com o livro homônimo de Nilton Bonder, Clarice Niskier, atriz com mais de 25 anos carreira, decide enfrentar o desafio de adaptar sozinha o livro para a cena. Sobre essa decisão, ela revela que foi levada a tal por uma necessidade ("como o ar que respiro") de correr esse risco, de se "responsabilizar pela concepção da peça" ${ }^{14}$. Uma escolha intimamente ligada a um modo pessoal de lidar com uma experiência interior, subjetiva, de cunho primordialmente existencial, segundo a própria atriz. Em um artigo da REVISTA APLASO, no 76, de julho/agosto de 2006, a atriz revela a sua ligação pessoal com o texto:

"o texto é muito revelador da alma humana e me fez entender a minha própria natureza. Eu sempre digo para o Nilton que, se eu fosse compositora, faria uma canção A Alma Imoral. Se fosse uma artista plástica, teria feito uma escultura chamada A Alma Imoral. Mas como sou atriz, resolvi levar para o teatro".

O espetáculo começa com uma conversa informal da atriz com o público, na qual ela conta as razões do espetáculo: de onde surgiu a idéia ${ }^{15}$, como ele foi sendo

12 http://www.flickr.com/photos/alessandracolasanti; http://www.flickr.com/photos/13914247@N02/page2/

${ }^{13} \mathrm{Na}$ minha última conversa com Clarice Niskier, no início de novembro, ela me informou que a peça já passou dos 100 mil espectadores e continua com a casa lotada, no Teatro Eva Hertz, em São Paulo.

${ }^{14} \mathrm{Em}$ entrevista de Clarice Niskier, publicada em 2006 no site da revista eletrônica de teatro Scene4 (http://www.archives.scene4.com/, para acessar a revista e http://www.scene4.com/archivesqv6/sep2006/html/carvalho-portsep06.html, para acessar a entrevista).

${ }^{15}$ A atriz nos conta, no prólogo da peça, que tudo começou em 2002, quando participou de um programa de entrevistas, tipo mesa-redonda, em que um dos convidados era o rabino Nilton Bonder e cujo tema era 
trabalhado, do que se trata a peça e, ainda, explica a possibilidade do público interpelála em determinados momentos se ele não estivesse entendendo muito bem alguma passagem. A conversa com o público se desenrola ao longo de todo espetáculo, dentro de uma encenação baseada no despojamento, pela não-representação. A atriz se apresenta nua, em um palco quase nu (o cenário que é uma estrada em perspectiva, como se a atriz estivesse num caminho), tendo como figurino um único tecido preto que se molda ao seu corpo fazendo referências aos episódios bíblicos contados por ela com grande precisão cênica. A dramaturga-atriz é em cena a sua própria alma ${ }^{16}$, compartilhando com o público conceitos sobre tradição, traição, certo e errado, obediência e fidelidade.

A Alma Imoral fechou o ano de 2006 com três indicações ao Prêmio Eletrobrás de Teatro (melhor atriz, melhor peça e melhor figurino) e chegou a 2007 com duas indicações ao Prêmio Shell (melhor atriz e melhor figurino), tendo vencido na categoria de melhor atriz. Foi ainda contemplada pelo Prêmio Caravana Funarte de Circulação Nacional de Teatro em 2007.

Com relação aos monólogos que tenho pesquisado, o que chama a atenção em torno da experiência do ator em construir os seus solo é a intensificação de suas autorreferências que incidem sobre a obra em processo, criando um chão particular sobre o qual a performance é erigida. Há uma primeira camada, que diz respeito à dimensão das escolhas pessoais que se revertem para o crescimento e prazer particulares das atrizes através do projeto artístico - um tipo de relação em que ator e criação se entrelaçam de modo especial (algo muito diverso dos casos em que o ator é selecionado num teste para fazer uma personagem numa grande montagem). No processo de criação, este confronto ou identificação entre as atrizes e sua obra (que é sua própria performance em cena) torna-se ainda mais palpável, sensível, delicado, penoso e

religião. Ao ser questionada sobre a sua religião, a atriz revelou que era meio judia e meio budista, gerando um comentário via fax de uma espectadora que a contestava, afirmando que não existia judiabudista (ou se é bem judia ou se é bem budista, segundo a senhora autora do fax). O rabino, neste momento, foi em defesa de Clarice e a presenteou com o seu livro A Alma Imoral, que acabou se tornando o seu grande projeto autoral assim que terminou de lê-lo.

${ }^{16}$ Sobre este aspecto, há muito ainda para se discutir, sobretudo em torno do tipo de self que está em cena, que é ao mesmo tempo "ela mesma", mas é também uma construção cênica muito particular, que segundo o discurso da atriz acaba por revelar quem ela é "de verdade", em toda a sua capacidade expressiva que a faz ir "além dela mesma". Um outro aspecto é a da escolha pela nudez. Para ela, essa peça só poderia ser encenada com verdade se ele estivesse nua. cena, mesmo com todas as suas implicações problemáticas (inclusive o fato de sentir vergonha). A alma é nua, e ela só poderia falar dessa alma se encarasse verdadeiramente essa condição. 
prazeroso. A criação, afinal, está nas mãos da atriz, de sua própria capacidade de entrar em contato (“descobrir", “construir", "exteriorizar") com seus "outros", explorar todas as suas próprias possibilidades de ser expressivo e ao mesmo tempo "verossímil", "verdadeiro", "honesto", "autêntico" - poder, sozinho, encarar a platéia e envolvê-la por seus próprios meios, seu traço especial, sua idiossincrasia espetacular.

Entretanto, é no momento em que o palco se ilumina e a realidade do teatro se impõe àqueles que vêem (e, em muitos casos, também são vistos) e àqueles que atuam, que o encontro entre criador e criatura - aos olhos e significação do público - se dá na confluência temporal da realidade fictícia da personagem, da realidade do ator/atriz que a cria, do espaço cênico e do público, partner reencontrado do solista e mesmo das personagens vividas por ele. Em cena, se espetacularizam não apenas as "figuras", "personas", "personagens", “arquétipos", “discursos" construídos pelo ator/atriz, mas, ao mesmo tempo e na mesma medida, o próprio ator - no monólogo, a capacidade do ator de tornar-se completamente "outro" não nos faz esquecer, pela própria "fragilidade" ilusionista do monólogo, de sua presença, que se impõe no próprio cara-acara com o público (que estaria numa esfera da realidade atual, não fictícia). É neste desafio ao "desmascaramento", sempre à espreita, que reside o risco e ambigüidade da exposição - que pode potencializar surpreendentemente a "verdade" do discurso (não é só o personagem que enuncia, mas também o ator é o sujeito da história que conta), gerando momentos de grande comoção na platéia, ou de esvaziamento da tensão cênica - por exemplo, com a perda da concentração, ao se romper o perigoso limite entre o fictício (controlado) e o presente (imprevisível). Com relação a esta tensão entre o ator e as suas máscaras, Alessandra Colasanti, em Anticlássico, vai ao limite da ambigüidade, criando uma personagem com uma imagem surrealista e ao mesmo tempo completamente integrada ao público, flertando comicamente com o limite entre a atriz e a sua criação. A própria atriz diz não mais saber o limite entre ela e a Bailarina, e que em várias situações quem está em cena é a Alessandra vestida de Bailarina e não uma personagem completamente distanciada (algo que a própria atriz acha um tanto estranho, "esquizofrênico", pois para ela, ambiguamente, a personagem não existe, quem existe é a atriz). Clarice leva ao extremo a sua própria presença em cena. Para ela, não há personagem no monólogo, e sim ela mesma que conta histórias e conversa com público, completamente despojada, embora obedecendo uma estrutura cênica muito precisa e por isso mesmo extremamente delicada. 
O monólogo - como é uma impressão minha - seria uma experiência privilegiada em que a autoria do ator - não apenas pelo fato de ter escrito o texto ou assinado a encenação - estaria mais explícita, mais exposta, mais à prova. Trata-se de uma modalidade teatral difícil, arriscada, onde o ator ou atriz estaria mais vulnerável pelo fato de o sucesso ou fracasso do espetáculo estar exclusivamente nas suas mãos. E, ao mesmo tempo, tomado como grande desafio, não seria também o espaço em que toda a competência, talento, carisma, entre outras qualidades, de um ator ou atriz estariam mais evidentes - e isso explicaria a profusão de prêmios de melhor ator e atriz para os solistas em cartaz nos últimos anos. Seria também uma autoexposição desafiadora, na qual o ator assume-se pronto e desejoso de ter os holofotes unicamente voltados para si, concentrando o olhar e a atenção do público, sem o qual o ato teatral não se completa. Mais do que um puro exercício narcísico (embora este não deva ser deixado de lado), o monólogo surge como uma necessidade ou um meio de se interrogar sobre caminhos e escolhas pessoais - como fora o impulso inicial do projeto A Alma Imoral de Clarice Niskier, a respeito de sua própria religiosidade - ou uma forma íntima de lidar com a aspereza da vida e com as coisas que mais ama - como revelara Alessandra Colasanti. O trabalho solo se configura como uma forma expressiva cênica preferencial que acessa e reelabora alguma dimensão particularmente preciosa da experiência subjetiva do ator. É este confronto com algum dado íntimo da experiência do ator que motiva o monólogo, o qual deve, por sua vez, expressar e fazer o espectador sentir esta tão particular centelha preciosa da vida do artista.

\section{4 - Alguns caminhos a seguir: o ator-autor e a obra como multi-objetivações de si}

Ao falar dos monólogos, refiro-me, sobretudo, a seus atores-autores. Aqui, não me baseio em conceituações nativas do que seria, a priori, mais ou menos "autoral" - a partir das quais peças consideradas comerciais e cômicas (logo, menos autorais) e peças mais "reflexivas" ou "intelectualizadas" (mais autorais) não estariam provavelmente lado a lado. Com relação aos monólogos, minha questão é justamente perceber a idéia da autoria por outros vieses - pela experiência subjetiva dos atores solos na construção de um "teatro seu", com a "sua cara", mesmo que tais obras possam ser criticamente vistas como baseadas em certa "previsibilidade" ou em "traços tradicionais", ou seja, pouco "inovadoras", segundo a crítica nativa, em termos de narrativa, tema, encenação e 
mesmo interpretação. Busco aqui, considerando a visão nativa, ver além dela, ou ainda, ampliá-la, percebendo outras possibilidades nativas de ser (e ver-se) autoral, sem seguir um determinado cânone local sobre o que seria um teatro "autoral" (próximo às idéias de performance, arte experimental, não-comercial, "séria").

É preciso deixar claro que, na relação indivíduo-criador e obra-monólogo, ambos os pólos são importantes para compreender, exatamente, como se dá este processo de construir uma obra sobre um outro - que é também o sujeito criador - e construir-se, perceber-se, definir-se através desta obra. Não obstante, a obra - que se manifesta em ato, na conjunção presente e processual das temporalidades do palco e da platéia - surge como o objetivo do artista, aquilo que ele oferece de si ao público. Para os fins desta pesquisa, ela é encarada como locus a partir e através de onde o ator-autor se faz, seja como artista, seja como discurso, seja como indivíduo, seja como desconstrução (isso dependerá da maneira própria como ele se relaciona com a obra e como esta o reflete e lhe atribui significados). Como o ator-autor, a partir de sua própria percepção subjetiva, se relaciona com esta obra - tal é o lugar a partir do qual analiso os monólogos, como produtos polissignificativos da experiência de indivíduos de nossa sociedade. E sem perder de vista o caráter processual da obra: ela se faz pela incorporação de todo o processo de criação que a põe em cena, alimentada continuamente pela relação com o olhar dos outros - é neste movimento que a experiência do criador se imbrica à experiência da obra, pois sua perspectiva subjetiva com relação à experiência da criação se relaciona, da mesma forma, com o processo da obra e com o olhar do público.

Como já expus, a própria experiência do monólogo implica um sujeito criador, no caso o ator, que não se coloca no papel (ou mesmo rebelde a esta posição) de mero executor de uma idéia alheia. Assim, seja no caso de uma comédia de tipos, de apelo comercial, seja num teatro abertamente performático e que se quer provocador, a experiência da autoria sempre está presente de modo fundamental para a própria construção da peça. Estas foram feitas por serem, todas, autorais no sentido de atender a um desejo essencial dos atores de fazerem um teatro a partir de sua idiossincrasia e na busca de maior liberdade no fazer teatral.

Ao buscar esta relação produtiva entre o ator-indivíduo e a sua obra, tenho enfocado, como ponto de partida, o modo como os atores exploram expressivamente as personagens (para usar um nome genérico) que conduzem a peça, a partir das quais 
pode-se entrever, de modo mais direto esta relação entre o ator e a sua obra. Acredito que ao enfocar as diferentes formas de construir, explorar, desdobrar personagens em cada monólogo, é possível enxergarmos, com mais nitidez e mais intimidade a ação autoral de cada ator e atriz no conjunto do espetáculo. É na relação do ator/atriz com seu personagem - a "máscara", nas suas mais diferentes acepções, com e através da qual ele/ela age no palco com e para a platéia - que todo o espetáculo se anima e ganha sentindo, que o texto se performa, torna-se acontecimento, que todos os artifícios visuais e sonoros encontram o seu eixo, seu suporte - na atuação do ator, na vida da personagem. No caso de Alessandra, temos a Bailarina de Vermelho, um tipo de construção bem diverso do registro realista, que subsiste além do palco ou da sua "Desconferência", mais próxima ao registro do palhaço, como uma personagem (nãonaturalista; não-psicológica) amalgamada à atriz-performer, um alter ego. No caso de Clarice Niskier, temos a atriz em cena, que interpreta "em cima de si mesma", como exposto por Cohen (1989) a propósito da multifragmentação do performer, em “A Alma Imoral". Em cada monólogo, em cada proposta autoral,vislumbramos novas possibilidades de construir o sujeito ou sujeitos da cena, em que todos atrelam-se interessantemente ao próprio criador e onde este vínculo é - de forma muito mais direta e, assim, complexa, do que nas propostas não-monológicas - parte essencial do espetáculo.

A partir da relação do ator-autor com a personagem - e deste amálgama, a relação com o público - podemos observar o confronto entre a experiência íntima do ator, que motiva e ao mesmo tempo dá forma e conteúdo (em várias camadas) à sua criação, e esta, a personagem, a figura que se dirige ao público e, com este, brinca de esconder e expor seu próprio criador. É através de sua própria composição em cena - a partir de um texto que, mais do que lhe dar sentido, trespassa a personagem - que nos relacionamos (como público) com a realidade discursiva que ela nos apresenta - um discurso que pode ser encarado como um comentário (que talvez somente no palco possa se desenrolar, através do corpo vivo do ator) de algo mais amplo: de nossas próprias possibilidades nativas de concebermos nossa experiência como indivíduos, como sociedade, como seres em processo, cujas identidades estão sempre em risco e em relação. Se o ator, através de sua personagem, apresenta diante de nós combinatórias de seu próprio $e u$, nós, no pólo da platéia, somos tomados de assalto - através da própria experiência de nos relacionarmos cognitiva e sensorialmente com a ação performada 
diante de nossos olhos - pela possibilidade de sermos, cada um, também "outros", também "em processo", também em constante atualização do que podemos ser.

\section{REFERÊNCIAS BIBLIOGRÁFICAS}

BECKER, Howard. Art Worlds. Berkeley and Los Angeles, California: University of California Press, 1982.

BERNAT, Isaac. O exercício criativo do ator em monólogos de Tchekov. Dissertação de mestrado. Programa de Pós-Graduação em Teatro, do Centro de Letras e Artes da Universidade do Rio de Janeiro - UNI-RIO, 1999.

BOURDIEU, Pierre. As Regras da Arte. São Paulo: Companhia da Letras, 1996 .

. Eléments pour une "critique vulguaire des critiques pures", in: La Distinction: critique sociale du jugement. Paris: Éditions du Minuit, 1979.

CLIFFORD, James e MARCUS, George (eds.). Writing culture. The poetics and politics of ethnography. Berkeley: University of California Press

CRAPANZANO, Vincent. Horizontes imaginativos e o aquém e além. Revista de Antropologia, v. 48, n. 1, São Paulo, 2005. p. 363-384.

COELHO, Maria Cláudia Pereira. A experiência da fama: individualismo e comunicação de massa. Rio de Janeiro: Editora FGV, 1999.

Teatro e Contracultura: um estudo de antropologia social, dissertação, Museu Nacional/PPGAS/ UFRJ, Rio de Janeiro, 1989.

COHEN, R. A performance como linguagem: criação de um tempo-espaço de experimentação. São Paulo: Perspectiva, (Debates 219)e Editora da Universidade de São Paulo, 1989.

Work in Progress na Cena Contemporânea: Criação, Encenação e Recepção. São Paulo Perspectiva Col. Estudos, 2006.

CONNOR, Steven. Cultura Pós-Moderna: introdução às teorias do contemporâneo. São Paulo: Edições Loyola, 1996, $3^{\mathrm{a}}$ ed.

DUARTE, Luiz Fernando Dias. Sujeito, soberano, assujeitado: paradoxos da pessoa ocidental moderna. IN: ARÁN, Marcia (org.). Soberanias. Rio de Janeiro: Contracapa, 2003;

DUMONT, Louis. Essais sur l'individualisme: une perspective anthropologique sur l ideologie moderne. Paris: Seuil, 1983 
ELIAS, Norbert. Mozart: Sociologia de um Gênio. Rio de Janeiro: Jorge Zahar Editor, 1995.

A Sociedade dos Indivíduos. Rio de Janeiro: Jorge Zahar Ed., 1994.

FRISBY, David. Simmel and Since: essays on Georg Simmel's Social Theroy. London: Routledge, 1992.

GEERTZ, Clifford. O saber local: novos ensaios em antropologia interpretativa. Petrópolis: Editora Vozes, 1997.

GLUSBERG, Jorge. A Arte da Performance. São Paulo: Perspectiva. Col. Debates 206, 2008.

GUINSBURG, Jaco e FARIA, João Roberto et LIMA, . Mariângela Alves. Dicionário do Teatro Brasileiro: temas, formas e conceitos. Editora Perspectiva, 2006.

LEVINE, Donald N. (ed.) On Individuality and Social Forms. Chicago: Chicago University Press, 1987.

MATTA, Roberto da. Individualismo e Liminaridade, in: Revista MANA, PPGAS/Museu Nacional, Rio de Janeiro, 2000.

MAUSS, Marcel. Uma categoria do espírito humano: a noção de pessoa, a noção do “eu”, in: Sociologia e antropologia. Vol. 1. São Paulo: E.P.U./EDUSP, 1974 (1934).

MILLER, Daniel. 1994. Artefacts and the Meaning of Things. In: Companion Encyclopedia of Anthropology. London: Routledge. pp. 396-419.

MORAES FILHO, E. de (org.) - Georg Simmel: Sociologia. São Paulo, Ática, 1983.

MORPHY, Howard.The anthropology of art. In: Tim Ingold (ed.), Companion Encyclopedia of Anthropology. London: Routledge. Pp. 648-685. 1994

MOURA, Cristiane. Solidão Anárquica: vocabulário de atitude do Teatro Essencial. Dissertação de mestrado na área de estudos do espetáculo. Programa de Pós-Graduação em Teatro, do Centro de Letras e Artes da Universidade do Rio de Janeiro - UNI-RIO, 1997.

PAVIS, Patrice. A Análise do Espetáculo. São Paulo: Editora Perspectiva. 2003. Dicionário de Teatro. $2^{\circ}$ ed. São Paulo: Perspectiva, 1999.

ROUBINE, Jean-Jacques. A arte do ator. Rio de Janeiro: Zahar, 1995.

1998. A linguagem da encenação teatral. Rio de Janeiro: Zahar, . Introdução às grandes teorias de teatro. Rio de Janeiro:

Zahar, 2003. 
RYNGAERT, Jean-Pierre. Introdução à análise de teatro. São Paulo: Martins Fontes, 1995.

RUBY, Jay. A Crack in the Mirror: Reflexive Perspectives in Anthropology. Philadelphia: University of Pennsylvania Press, 1983.

SCHECHNER, Richard. Ritual and Performance. in: Companion Encyclopedia of Anthropology. Edited by Tim Inglod. London and New York: Routledge.

SILVA, Ana Amélia Brasileiro Medeiros. Quando se segue uma borboleta: estudantes de teatro, expectativas, sonhos e dilemas em torno da profissão de ator. Dissertação de Mestrado, PPGSA/ IFCS/UFRJ, Rio de Janeiro, 2003. or. Elsje Maria Lagrou

SIMMEL, Georg. El individuo y la libertad: ensayos de crítica de la cultura. Barcelona: Península, 1986.

A metrópole e a vida mental. in: O fenômeno urbano. Rio: Zahar, 1987. . On Individuality and Social Forms. Chicago, University of Chicago Press, 1971. . Subjective Culture. In: On individuality and social forms - selected wrintings. Chicago and London: The University of Chicago Press, 1971.

STANISLAVSKI, Constantin. A construção da personagem. Civilização Brasileira $4^{\mathrm{a}}$ edição 1986.

TAUSSIG, Michael. Mimesis and Alterity. A Particular History of the Senses. New York/London: Routledge. 1993. Cap. 1. pp. 1-18.

TROTTA, Rosyane. Paradoxo do Teatro de Grupo. Dissertação de Mestrado. Rio de Janeiro: Universidade do Rio de Janeiro (UNI-RIO), Programa de Pós-Graduação em Teatro Centro de Letras e Artes, 1995.

TURNER, Victor. The Anthropology of Performance. New York : PAJ Publications, 1987.

From Ritual to Theatre: The Human Seriousness of Play. New York: PAJ publications, 1982.

VELHO, Gilberto. Autoria e Criação Artística. In: Artifícios \& Artefactos. Rio de Janeiro: 7 Letras, 2006.

Individualismo e Cultura: Notas para uma Antropologia da Sociedade Contemporânea. Rio Janeiro: Jorge Zahar Editor. $4^{\text {a }}$ editora, 1997.

WERNECK, M. H. V. Monólogos Brasileiros: poéticas da primeira pessoa e espacialidades. no IV Congresso da ABRACE; Memória ABRACE, Sete Letras, Rio de Janeiro, v. 1, n. 1, 2006 (texto publicado nos anais). 